\title{
Identification of Species in the Botryosphaeriaceae Family Causing Stem Blight on Southern Highbush Blueberry in Florida
}

\author{
A. F. Wright and P. F. Harmon, Department of Plant Pathology, University of Florida, Gainesville 32611
}

\begin{abstract}
Wright, A. F., and Harmon, P. F. 2010. Identification of species in the Botryosphaeriaceae family causing stem blight on southern highbush blueberry in Florida. Plant Dis. 94:966-971.

Stem blight of southern highbush blueberry (SHB) results in premature plant mortality and has been identified by Florida blueberry growers as the economically most important disease for the industry. In 2007, plants with stem blight and dieback symptoms were sampled at 4-month intervals from two farms located in Alachua and Polk Co., FL. In all, 30 cane samples (stem blight) and 30 crown segments (dieback) were collected at each sample date and each location. In total, 360 samples were collected; fungal species in the family Botryosphaeriaceae were isolated from $85 \%$ of the samples. Based on morphology and phylogenetic analysis of the internal transcribed spacer region and elongation factor $1-\alpha(E F 1-\alpha)$ sequences, two dominant species recovered from SHB in Florida were identified: Lasiodiplodia theobromae and Neofusicoccum ribis. Species isolation was independent of location, symptom type, and time of year. Additional samplings are needed to investigate population change over multiple years and in the rest of the southeastern United States. Breeding for resistance and management of stem blight and dieback in Florida should focus on these two fungal species.
\end{abstract}

The Florida southern highbush blueberry (SHB; interspecific Vaccinium corymbosum and $V$. darrowi hybrid) industry has an early-season high-dollar niche market (34). Blueberry production has doubled since the early 1980s; currently, Florida ranks fifth in the United States for commercial acreage $(34,35)$. Fungal vascular diseases have become an important problem for blueberry growers. Pathogens enter through flower buds, lenticels, stomata, and wounds and colonize the vascular system $(5,14,15,19,30)$.

Florida blueberry growers have identified stem blight and dieback symptoms that result in premature plant mortality as the economically most important disease problems they face. Stem blight typically infects current-season growth and can progress rapidly down the vasculature (15). Symptoms include rapid witling and reddening of leaves on affected branches. Partial or complete occlusion of the vasculature results in brown discoloration, typically on one side of the infected branch $(15,36)$. A single branch with terminal leaf and stem blight symptoms as described above is referred to as the stem blight in the current study. In severe cases, infection progresses into the crown of the plant and results in systemic branch dieback over a

Corresponding author: P. F. Harmon

E-mail: pfharmon@ufl.edu

Accepted for publication 5 April 2010.

doi:10.1094/PDIS-94-8-0966

(C) 2010 The American Phytopathological Society period of weeks or months, eventually killing the plant. Systemic dieback associated with crown infection is referred to as dieback in this study. Mortality associated with dieback limits production and results in substantial replant costs. Fungicide applications (15), optimizing irrigation practices (8), and aggressive pruning for the control of stem blight increase production costs and cannot adequately manage the disease (32).

Species in the family Botryosphaeriaceae typically have a wide host range and geographical distribution (24). These fungi are largely considered drought-stress opportunistic pathogens and live as saprophytes or endophytes most of the time $(10,27)$. Species identification has been difficult because multiple species have been found parasitizing the same host $(3,4,30,31)$. Virulence of and symptoms caused by Botryosphaeria spp. have been reported to be different depending on cultivar and location (30).

The anamorphs of Botryosphaeria spp. occur frequently on infected tissue and are primarily used for identification $(9-11,36)$. Anamorphic characteristics have phenotypic variation and are similar among species $(11,21)$. Eighteen anamorphic genera have been associated with Botryosphaeria spp. and, currently, 10 lineages are recognized within the family Botryosphaeriaceae (9). Phylogenetic studies using morphological characterization and genomic data have contributed to the clarification of Botryosphaeria spp. taxonomy $(9,11,21,39)$. Molecular data have allowed for the positive and rapid identification of species in the Botryosphaeriaceae family parasitizing grapes (6,29-31), mango (22), and pistachio (12).

Witcher and Clayton (36) described Botryosphaeria dothidea as the causal agent of stem blight of blueberry. At the time, $B$. ribis and 23 other named fungal species were considered synonyms of $B$. dothidea (21,36). Pennycook and Samuels (17) accepted the synonyms for $B$. dothidea and described $B$. parva. Based on multigene phylogeny, B. ribis (anamorph Neofusicoccum ribis) is considered to be a separate species from $B$. dothidea (anamorph Fusicoccum aesculi) and B. parva (anamorph $N$. parvum) $(9,21)$. However, $N$. parvum and $N$. ribis cannot be distinguished based on internal transcribed spacer (ITS) rDNA sequences $(21,25,39)$ and restriction fragment length polymorphism analysis (23). Conidial morphology between the species is similar but conidia of $N$. parvum are slightly smaller than those of $N$. ribis and turn brown and multiseptate with age (21). Partial sequences of the elongation factor $1-\alpha(E F 1-\alpha)$, a portion of RNA polymerase II subunit, and slight differences in conidial morphology are used to distinguish the two species $(16,21,31)$.

The species of fungi that cause the most important dieback and stem blight symptoms of SHB in Florida are unknown. Fungi such as Diplodia, Macrophoma, and Phomopsis spp. have been reported to cause these types of symptoms (1). The objective of this study was to identify to species the predominant causal agents associated with stem blight and dieback symptoms of SHB in Florida.

\section{MATERIALS AND METHODS}

Sample material collection and pathogen isolation. Stem blight samples consisted of partially hardened succulent stems from current-season growth. Dieback samples consisted of a major cane and were taken no further than $12 \mathrm{~cm}$ above the crown of a plant. Samples were collected periodically from two farms in Florida: the first was located in Alachua County (north-central Florida) and the second was located $225 \mathrm{~km}$ south in Polk County (central Florida). A farm-wide survey of disease was made at each location at four-month intervals (January to February, June to July, and October to November) in 2007; 30 samples of each stem blight and dieback symptom were collected from both farms during a survey period. Other samples outside the survey 
included isolates from Vaccinium virgatum, SHB samples from the Florida Extension Plant Disease Clinic, Ilex spp. (common near blueberry fields in Florida), and isolates from a foliar ring spot symptom on the SHB cvs. Millennia and Star (Table 1). Samples outside the survey were included for comparison with samples collected from the two farms. Bark of blueberry samples was removed to expose the discolored vasculature and margins were excised and cut into small pieces. Four pieces of each sample were surface disinfested in $10 \%$ household bleach $(0.615 \%$ sodium hypochlorite) for $1 \mathrm{~min}$ and rinsed with distilled water. Tissue samples were dried with a paper towel and plated on 85$\mathrm{mm}$ petri dishes containing V8 juice agar (15.0 $\mathrm{g}$ of agar, $200 \mathrm{ml}$ of V8 juice, and 2.0 $\mathrm{g}$ of $\mathrm{CaCO}_{3}$ per liter) amended with 0.01 $\mathrm{mg}$ of rifampicin and $0.25 \mathrm{~g}$ of ampicillin sodium salt per liter. Cultures were incubated at $25^{\circ} \mathrm{C}$ for 5 days. Fungal isolates were obtained by transferring mycelial fragments from the margins of expanding colonies. Isolates were stored on filter paper disks and maintained in a $5^{\circ} \mathrm{C}$ refrigerator.

The remaining portions of samples after plating were incubated at $25^{\circ} \mathrm{C}$ for 2 weeks in sealed plastic bags with a moist paper towel. All samples were checked for the presence of sporulating structures after incubation, and the number of samples per location and sample period were counted. If asexual structures were observed, conidia were identified by morphological characteristics. Likewise, if sexual fruiting bodies were observed, isolations were made from single-spore serial dilutions onto plates of potato dextrose agar (PDA)
(BD, Sparks, MD). Mycelial fragments from the margins of single-spore colonies were excised, transferred, and stored as described above.

DNA extraction, amplification, and phylogenetic analysis. Genomic DNA from 219 isolates randomly selected from storage was extracted using the Qiagen DNeasy Kit (Qiagen, Santa Clarita, CA). After extraction, oligonucleotide primers ITS1 and ITS4 were used to amplify the ITS1 and ITS2 and 5.8s regions of rDNA (33). A partial sequence of EF1- $\alpha$ was amplified using primers EF1-728 and EF1928 (Integrated DNA Technologies, Inc., Coralville, IA) (7). Polymerase chain reaction (PCR) mixtures included: $10 \mu \mathrm{l}$ of RED Extract-N-Amp PCR mix (SigmaAldrich, St. Louis), $2 \mu$ of each primer, 2 $\mu \mathrm{l}$ of PCR-grade water, and $4 \mu \mathrm{l}$ of extracted DNA. The thermocycler program (Brinkman Instruments, Inc., Westbury, NY) used with ITS primers included an initial denaturing step of $3 \mathrm{~min}$ at $94^{\circ} \mathrm{C}$ followed by 35 cycles of denaturing at $94^{\circ} \mathrm{C}$ for $60 \mathrm{~s}$, annealing at $55^{\circ} \mathrm{C}$ for $60 \mathrm{~s}$, and extension at $72^{\circ} \mathrm{C}$ for $60 \mathrm{~s}$. A final extension at $72^{\circ} \mathrm{C}$ was held for $10 \mathrm{~min}$. Likewise, the EF1- $\alpha$ program included an initial denaturing step of $3 \mathrm{~min}$ at $94^{\circ} \mathrm{C}$ followed by 40 cycles of denaturing at $94^{\circ} \mathrm{C}$ for $60 \mathrm{~s}$, and annealing at $60^{\circ} \mathrm{C}$ for $45 \mathrm{~s}$, and extension at $72^{\circ} \mathrm{C}$ for $60 \mathrm{~s}$. A final extension at $72^{\circ} \mathrm{C}$ was held for 10 $\min$. For each PCR product, $5 \mu \mathrm{l}$ was separated by gel electrophoresis in $1.2 \%$ agarose gels (Fisher Scientific, Fair Lawn, NJ) containing $0.5 \mu \mathrm{g}$ per $1 \mathrm{ml}$ of ethidium bromide in a Tris-borate buffer (SigmaAldrich). Each unrefined PCR product (5 $\mu \mathrm{l})$ was placed on half of a 96-well PCR plate that was sent to the University of Florida's Interdisciplinary Center for Biotechnology Research for bidirectional sequencing with the PCR primers.

Sequences were edited using the software program Sequencher 4.6 (Gene Codes, Corp., Ann Arbor, MI), locally aligned using Clustal $X$ 2.06-macosx (Conway Institute, UCD., Dublin) (28) and manually aligned using the computer software McClade 4.08 OSX (Sinauer Associates, Inc., Sunderland, MA) (13). Phylogenetic analysis was completed using PAUP $4.0 \mathrm{bl0}$ (Sinauer Associates) (26). Alignment gaps were treated as missing data. Twenty-two isolates from the survey (Table 1) were compared using phylogenetic analysis to related sequences published in GenBank (Table 2). Isolate CMW7063 (a Bionectria sp.) was used as the outgroup for phylogenetic analysis. Separate and combined phylogenetic analyses were run for both data sets. A partition homogeneity test was used to determine whether ITS and EF1- $\alpha$ regions could be combined. Maximum parsimony analysis was performed using the heuristic search option (NNI branch swapping). Bootstrap values were evaluated using 1,000 replicates and 100 random sequence additions to test branch strength. Tree length, consistency index $(\mathrm{CI})$, and retention index (RI) were recorded for all analyses.

Morphological characterization. Thirty Botryosphaeriaceae isolates identified based on sequence data were further characterized by conidial morphology and colony growth characteristics. Conidia used for characterization were produced on PDA and in planta following cut-stem inoculations. Isolates taken from storage

Table 1. Representative isolates from Florida sample collections used in phylogenetic analysis

\begin{tabular}{|c|c|c|c|c|c|c|}
\hline \multirow[b]{2}{*}{ Species $^{\mathbf{a}}$} & \multirow[b]{2}{*}{ Origin } & \multirow[b]{2}{*}{ Collected } & \multirow[b]{2}{*}{ Host $^{\text {b }}$} & \multirow[b]{2}{*}{ Abbreviation } & \multicolumn{2}{|c|}{ GenBank accession no. } \\
\hline & & & & & ITS $^{\mathbf{c}}$ & EF1- $\alpha^{d}$ \\
\hline Neofusicoccum ribis & Archer, FL & August 2004 & SHB & UF0440 & FJ877139 & GQ845100 \\
\hline Lasiodiplodia theobromae & Apopka, FL & May 2005 & ILL & UF05161 & GQ845096 & GQ850468 \\
\hline Botryosphaeria dothidea & Wildwood, FL & February 2007 & SHB & UF0730 & GU595170 & GQ869643 \\
\hline B. dothidea & Archer, FL & August 2007 & SHB & ARSM & GU595171 & GQ869644 \\
\hline N. ribis & Archer, FL & August 2007 & SHB & ARS & GQ845088 & GQ845108 \\
\hline N. ribis & Waycross, GA & May 2007 & SHB & GAC1 & GQ336828 & GQ845103 \\
\hline N. ribis & Hawthorne, FL & May 2007 & REB & Rbe2 & GQ845087 & GQ845107 \\
\hline N. ribis & Windsor, FL & August 2007 & SHB & WRS2 & GQ336829 & GQ845104 \\
\hline L. theobromae & Polk County, FL & October 2007 & SHB & MixFF1 & GQ845093 & GQ850465 \\
\hline N. ribis & Polk County, FL & October 2007 & SHB & MixFF8 & GQ336826 & GQ845101 \\
\hline N. ribis & Polk County, FL & June 2007 & SHB & $\mathrm{MixSuC4}$ & GQ845092 & GQ845112 \\
\hline N. ribis & Alaucha County, FL & November 2007 & SHB & WFC25 & GQ845090 & GQ845110 \\
\hline N. ribis & Alaucha County, FL & November 2007 & SHB & WFF10 & GQ845091 & GQ845111 \\
\hline N. ribis & Alaucha County, FL & November 2007 & SHB & WFF9 & GQ845089 & GQ845109 \\
\hline L. theobromae & Alaucha County, FL & November 2007 & SHB & WFF92 & GQ845095 & GQ850467 \\
\hline N. ribis & Alaucha County, FL & June 2007 & SHB & WsuC17 & GQ336827 & GQ845102 \\
\hline N. ribis & Alaucha County, FL & June 2007 & SHB & WSuF16 & GQ336831 & GQ845106 \\
\hline N. ribis & Alaucha County, FL & January 2007 & SHB & WWC38 & GQ336830 & GQ845105 \\
\hline L. theobromae & Alaucha County, FL & January 2007 & SHB & WWF37 & GQ845099 & GQ850471 \\
\hline L. theobromae & Alaucha County, FL & February 2007 & SHB & WMixC35 & GQ845097 & GQ850469 \\
\hline L. theobromae & Polk County, FL & February 2007 & SHB & WmixF13 & GQ845094 & GQ850466 \\
\hline L. theobromae & Polk County, FL & February 2007 & SHB & WmixF27 & GQ845098 & GQ850470 \\
\hline
\end{tabular}

${ }^{a}$ Fungi identified based on morphology and phylogenetic analyses.

b $\mathrm{SHB}=$ Southern highbush blueberry; ILL = Illex cassine $; \mathrm{REB}=$ Vaccinium virgatum .

c Internal transcribed spacer region.

${ }^{\mathrm{d}}$ Elongation factor $1-\alpha$. 
were plated directly onto PDA and were incubated at $25^{\circ} \mathrm{C}$ with $12 \mathrm{~h}$ of light per day. Conidia production occurred after 5 weeks for most isolates.

$\mathrm{Cv}$. Jewel was used for stem inoculations. An 8-mm mycelium plug was taken from the margin of a 3-day-old colony of selected isolates. Plugs were secured with Parafilm (Pechiney Plastic Packaging, Co., Chicago), and lesions were allowed to develop. After 10 days, pycnidia were visible on plant stems. The length and width of 60 conidia of each isolate pro- duced on PDA or by stem inoculations was measured with a compound microscope using the imaging software Q-capture pro (QImaging, Surry, Canada). Mean and standard deviation of conidial measurements were analyzed in SAS (SAS institute, Cary, NC) using summary statistics. Conidial color, shape, and presence or absence of septations also were recorded.

Botryosphaeriaceae isolates selected for conidial characterization also were used for temperature growth studies. A 5-mm plug was taken from the margin of a 3- day-old colony and placed in the center of an $85-\mathrm{mm}$ petri plate. Three replicates of each isolate were incubated separately at 5 , $10,15,20,25,30,35$, and $40^{\circ} \mathrm{C}$ in the dark. Pigmentation was recorded if present at a particular temperature. Colony diameter was measured after 12,24 , and $36 \mathrm{~h}$ of growth. Data were converted to radial growth rate in millimeters using the measurements from 12 and $36 \mathrm{~h} \mathrm{(mm/day)}$ (20). The experiment was conducted twice. A $t$ test determined whether data from both experiments could be combined. Average

Table 2. Isolates not collected in this study but used for comparison in phylogenetic analysis

\begin{tabular}{|c|c|c|c|c|c|}
\hline \multirow[b]{2}{*}{ Isolate $^{\mathrm{a}}$} & \multirow[b]{2}{*}{ Species } & \multirow[b]{2}{*}{ Host } & \multirow[b]{2}{*}{ Origin } & \multicolumn{2}{|c|}{ GenBank accession no. } \\
\hline & & & & ITS $^{b}$ & EF1- $\alpha^{c}$ \\
\hline CBS119047 & Botryosphaeria corticis & Vaccinium corymbosum & New Jersey, United States & DQ299245 & EU017539 \\
\hline CBS119048 & B. corticis & V. coyrmbosum & New Jersey, United States & DQ299246 & EU017540 \\
\hline CBS9075 & B. dothidea & Populus nigra & New Zealand & AY236950 & AY236899 \\
\hline CBS 116741 & B. dothidea & P. nigra & Portugal & AY640254 & AY236890 \\
\hline CMW1130 & B. parva & Sequoia gigantean & South Africa & AY236945 & AY236890 \\
\hline CBS110301 & B. parva & Vitus vinifera & Portugal & AY259098 & AY573221 \\
\hline CMW7054 & B. ribis & Ribis rubrum & New York, United States & AF241177 & AY236879 \\
\hline CMW7773 & B. ribis & Ribis sp. & New York, United States & AY236936 & AY236878 \\
\hline CBS447.62 & Lasiodiplodia pseudotheobromae & Citrus aurantium & Suriname & EF622081 & EF622060.1 \\
\hline CBS190.73 & L. theobromae & Persea americana & Tanzania & EF622068 & EF622048 \\
\hline CMW7063 & Bionectria sp. & Taxus baccata & Netherlands & AY23656 & AY236905 \\
\hline
\end{tabular}

a Acronyms of culture collections: CMW = Culture Collection Forestry and Agricultural Biotechnology Institute, University of Pretoria, South Africa; and CBS = Contraalbureau Schimmelcultures, Utrecht, Netherlands.

${ }^{\mathrm{b}}$ Internal transcribed spacer region.

${ }^{\mathrm{c}}$ Elongation factor $1-\alpha$.

Table 3. Isolation results from sampling effort and preliminary identification of a select group of isolates using the sequences of the internal transcribed spacer region

\begin{tabular}{|c|c|c|c|c|c|c|c|c|}
\hline \multirow[b]{2}{*}{ Survey period, sample type } & \multirow[b]{2}{*}{ Colony ${ }^{c}$} & \multirow[b]{2}{*}{ Seq. ${ }^{\mathrm{d}}$} & \multicolumn{2}{|c|}{ Neofusicoccum ribis ${ }^{\mathrm{a}}$} & \multicolumn{2}{|c|}{ Lasiodiplodia theobromae $^{\mathrm{b}}$} & \multicolumn{2}{|c|}{ Other } \\
\hline & & & No. & Percent & No. & Percent & No. & Percent \\
\hline \multicolumn{9}{|l|}{ Winter (January-February) } \\
\hline \multicolumn{9}{|l|}{ Alachua County } \\
\hline Stem blight & 25 & 17 & 14 & 82 & 3 & 18 & 0 & $\ldots$ \\
\hline Dieback & 27 & 20 & 13 & 65 & 7 & 35 & 0 & $\ldots$ \\
\hline Subtotal & 52 & 37 & 27 & 73 & 10 & 27 & 0 & $\ldots$ \\
\hline \multicolumn{9}{|l|}{ Polk County } \\
\hline Stem blight & 18 & 18 & 17 & 85 & 2 & 10 & 1 & 5 \\
\hline Dieback & 29 & 21 & 12 & 57 & 9 & 43 & 0 & $\ldots$ \\
\hline Subtotal & 47 & 31 & 29 & 71 & 11 & 27 & 1 & 2 \\
\hline Winter total & 99 & 78 & 56 & 72 & 21 & 27 & 1 & 1 \\
\hline \multicolumn{9}{|l|}{ Summer (June-July) } \\
\hline \multicolumn{9}{|l|}{ Alachua County } \\
\hline Stem blight & 24 & 19 & 18 & 95 & 1 & 5 & 0 & $\ldots$ \\
\hline Dieback & 23 & 15 & 9 & 60 & 4 & 27 & 2 & 13 \\
\hline Subtotal & 47 & 34 & 27 & 79 & 5 & 15 & 2 & 6 \\
\hline \multicolumn{9}{|l|}{ Polk County } \\
\hline Stem blight & 24 & 16 & 11 & 69 & 3 & 19 & 2 & 12 \\
\hline Dieback & 21 & 14 & 11 & 85 & 2 & 15 & 0 & $\ldots$ \\
\hline Subtotal & 45 & 29 & 22 & 76 & 5 & 17 & 2 & 7 \\
\hline Summer total & 92 & 63 & 49 & 78 & 10 & 16 & 4 & 6 \\
\hline \multicolumn{9}{|l|}{ Fall (October-November) } \\
\hline \multicolumn{9}{|l|}{ Alachua County } \\
\hline Stem blight & 30 & 23 & 20 & 87 & 3 & 13 & 0 & $\ldots$ \\
\hline Dieback & 30 & 18 & 14 & 78 & 4 & 22 & 0 & $\ldots$ \\
\hline Subtotal & 60 & 41 & 34 & 83 & 7 & 27 & 0 & $\ldots$ \\
\hline \multicolumn{9}{|l|}{ Polk County } \\
\hline Stem blight & 26 & 20 & 14 & 70 & 4 & 20 & 2 & 10 \\
\hline Dieback & 29 & 17 & 11 & 65 & 6 & 35 & 0 & $\ldots$ \\
\hline Subtotal & 55 & 37 & 25 & 68 & 10 & 27 & 2 & 5 \\
\hline Fall total & 115 & 78 & 59 & 76 & 17 & 22 & 2 & 2 \\
\hline
\end{tabular}

${ }^{a}$ Sequenced isolates identified as Neofusiccocum ribis.

${ }^{\mathrm{b}}$ Sequenced isolates identified as Lasiodiplodia theobromae.

${ }^{c}$ Number of samples that Botryosphaeria-like fungi were isolated from out of 30 per symptom type.

${ }^{\mathrm{d}}$ Number of isolates sequenced from total recovered. 
radial growth rate versus temperature was plotted in SAS. Multiple regression curves were fit to the data in SAS using the Proc. Reg. function. After the regression equations were derived, the quadratic equation was used to calculate the optimum temperature of the regression curves.

\section{RESULTS}

Field survey, fungal isolation, and molecular characterization. Colonies consistent with Botryosphaeria spp.-like growth were isolated from 99 of 120 samples in the winter, 92 of 120 samples in the summer, and 115 of 120 samples in the fall (Table 3). Overall, colonies consistent with Botryosphaeria spp.-like growth were isolated from $85 \%$ of the 360 samples. Other fungal genera were isolated from approximately $15 \%$ of blueberry samples, including Alternaria, Pestalotia, and Phomopsis spp.

Identification of isolates from colonies consistent with morphology and growth characteristics of fungi in the family Botryosphaeriaceae was based on ITS sequence data and was confirmed by isolate morphology (Tables 3-5). The total number of isolates sequenced from the winter, summer, and fall collection periods were 78, 63, and 78, respectively. Fungi isolated included Lasiodiplodia theobromae and $N$. ribis, and other fungi such as Alternaria and Phomopsis spp. Both species in the Botryosphaeriaceae family were recovered from stem blight and dieback samples (Table 3). B. dothidea was isolated twice from samples outside the survey area.

Fruiting structures were observed in the fall at each sample location. Pycnidia were observed on 11 and 18 samples from Alachua and Polk Counties, FL. Conidia morphology was used to identify samples with pycnidia. L. theobromae was recovered from 10 samples in Alachua County and from 17 samples in Polk County. N. ribis was recovered once from each location in the fall. Likewise, perithecia were observed on one sample at each location.
All samples with perithecia were identified as $B$. ribis.

Phylogenetic characterization. ITS and EF1- $\alpha$ sequences of isolates were compared with homologous sequences published in GenBank (Fig. 1). A partition homogeneity test indicated that the ITS and EF1- $\alpha$ datasets could be combined ( $P$ $=0.77$ ). Of the 867 nucleotides analyzed, 203 were parsimony informative. Maximum parsimony analysis yielded one most parsimonious tree (length $=691, \mathrm{CI}=$ 0.89 , RI $=0.95$; Fig. 1). Tree topology was consistent with the ITS tree. Species in the Botryosphaeriaceae family with hyaline thin-walled conidia formed a monophyletic clade supported by an $84 \%$ bootstrap value, and included $B$. corticis, B. dothidea, $N$. parvum, and $N$. ribis. Isolates of $L$. theobromae with thick-walled, pigmented conidia grouped in a clade supported by a $99 \%$ bootstrap value. Intraspecific variation was present within the clade. $B$. dothidea and $B$. corticis grouped in a clade separate from $N$. ribis and $N$. parvum and were supported by a $100 \%$ bootstrap value.

Morphology. All isolates could be separated into two groups based on conidial characteristics. One group was characterized by the production of brownpigmented, thick-walled conidia and included $L$. theobromae. The second group was characterized by the production of hyaline, thin-walled conidia and included $F$. aesculi and $N$. ribis. Conidial dimensions recorded for these fungi are shown in Table 4, along with previously reported dimensions.

A cubic polynomial model best fit the data. All isolates grew over a range of temperatures $\left(15\right.$ to $\left.35^{\circ} \mathrm{C}\right)$ and the optimum temperature of approximately $30^{\circ} \mathrm{C}$ did not vary between species (Table 5). None of the isolates tested grew at either 5 or $10^{\circ} \mathrm{C}$ after $36 \mathrm{~h}$. L. theobromae was the only species to exhibit slight growth at $40^{\circ} \mathrm{C}$, and displayed bright pink pigment at temperatures $\geq 35^{\circ} \mathrm{C}$. Likewise, $N$. ribis isolates displayed a yellow pigment at temperatures from 20 to $30^{\circ} \mathrm{C}$. Among the fungi tested, $L$. theobromae had the highest mycelial growth rate at the optimum temperature after $36 \mathrm{~h}$, followed by $N$. ribis and $B$. dothidea (Table 4). No significant variation was present between isolates of the same species at each temperature.

Table 5. Optimum temperature and growth rate of fungi in the family Botryosphaeriaceae from Florida in comparison with those reported from previous studies

\begin{tabular}{|c|c|c|c|c|c|}
\hline \multirow[b]{2}{*}{ Species, isolate } & \multicolumn{2}{|c|}{ This study } & \multicolumn{2}{|c|}{ Previous studies } & \multirow[b]{2}{*}{ Reference } \\
\hline & Opt. $\left({ }^{\circ} \mathrm{C}\right)^{\mathrm{a}}$ & Growth rate ${ }^{b}$ & Opt. $\left({ }^{\circ} \mathrm{C}\right)^{\mathrm{a}}$ & Growth rate ${ }^{c}$ & \\
\hline \multicolumn{6}{|c|}{ Botryosphaeria dothidea } \\
\hline UF0730 & 28 & $13.6 \pm 0.6$ & $25-30$ & 12.5 & 17 \\
\hline ARSM & 29 & $11.7 \pm 0.3$ & $28-29$ & 11.1 & 21 \\
\hline \multicolumn{6}{|c|}{ Lasiodiplodia theobromae } \\
\hline UF05161 & 30 & $17.8 \pm 0.8$ & $30-35$ & 10.6 & 30 \\
\hline WFF92 & 29 & $17.5 \pm 0.4$ & 30.8 & 10.0 & 31 \\
\hline WmixC35 & 30 & $18.3 \pm 1.4$ & & & \\
\hline N. parvum & $\ldots$ & $\ldots$ & $28-29$ & 18.2 & 17 \\
\hline & $\ldots$ & $\ldots$ & 27.8 & 8.8 & 31 \\
\hline \multicolumn{6}{|c|}{ Neofusicoccum ribis } \\
\hline rbe2 & 29 & $11.5 \pm 0.8$ & 25 & 16 & 21 \\
\hline WsuF16 & 27 & $12.6 \pm 1.3$ & 28 & $\ldots$ & 36 \\
\hline WRS2 & 28 & $13.0 \pm 0.6$ & $\ldots$ & $\ldots$ & $\ldots$ \\
\hline
\end{tabular}

${ }^{a}$ Optimum temperature is defined as the maximum radial growth after $36 \mathrm{~h}$.

${ }^{\mathrm{b}}$ Average $(n=6)$ radial growth and standard deviation in millimeters per day at $30^{\circ} \mathrm{C}$.

${ }^{c}$ Average radial growth in millimeters per day at various temperatures.

Table 4. Dimensions of conidia of fungi in the family Botryosphaeriaceae from Florida in comparison with those reported from previous studies

\begin{tabular}{|c|c|c|c|}
\hline Species, isolate & Isolates from this study $(\text { mean and } \mathrm{SD}[\mu \mathrm{m}])^{\mathrm{a}}$ & Fungi from previous studies (conidia size $[\mu \mathrm{m}])^{\mathbf{b}}$ & Reference \\
\hline Botryosphaeria corticis & $\ldots$ & $23.5-32.5 \times 5.5-7$ & 18 \\
\hline \multicolumn{4}{|l|}{ B. dothidea } \\
\hline UF0730 & $26.0 \pm 1.6 \times 5.5 \pm 0.7^{\mathrm{c}}$ & $(15-) 20-26(-32) \times(4-) 5-6(-9)$ & 17 \\
\hline ARSM & $26.2 \pm 2.1 \times 5.8 \pm 0.6^{\mathrm{c}}$ & $(20-) 23-27(-30) \times 4-6(-6)$ & 21 \\
\hline \multicolumn{4}{|l|}{ Lasiodiplodia theobromae } \\
\hline UF05161 & $29.9 \pm 1.4 \times 16.4 \pm 0.9^{c}$ & $(-20) 23-27(-30) \times(-10) 11-13(-14)$ & 30 \\
\hline WFF92 & $29.4 \pm 3.2 \times 14.3 \pm 1.4^{\mathrm{c}}$ & $(18-) 20-25 \times(9) 11-14$ & 31 \\
\hline WmixC35 & $25.9 \pm 2.5 \times 14.5 \pm 1.1^{\mathrm{c}}$ & & \\
\hline \multirow{2}{*}{ Neofusicoccum parvum } & $\ldots$ & $(11-) 14-18(-23) \times(5-) 6-7(-9)$ & 17 \\
\hline & $\ldots$ & $(10-) 14.5-17 \times(5) 7-9$ & 30 \\
\hline \multicolumn{4}{|l|}{ N. ribis } \\
\hline rbe2 & $20.7 \pm 2.0 \times 6.6 \pm 0.9^{\mathrm{d}}$ & $(16-) 19-23(-24) \times 5-6(-7)$ & 21 \\
\hline WsuF16 & $20.3 \pm 1.9 \times 6.6 \pm 0.7^{\mathrm{d}}$ & $16-22.9 \times 4.9-7.8$ & 36 \\
\hline WRS2 & $20.3 \pm 1.8 \times 6.8 \pm 0.7^{\mathrm{d}}$ & $\ldots$ & $\ldots$ \\
\hline
\end{tabular}

${ }^{a}$ Average length, width, and standard deviation (SD) of 60 conidia from each isolate.

${ }^{b}$ Minimum size, most common values, and maximum size for length and width of conidia.

${ }^{\mathrm{c}}$ Conidia produced directly on potato dextrose agar.

${ }^{\mathrm{d}}$ Conidia produced by stem inoculations. 


\section{DISCUSSION}

The Florida SHB industry has two primary pathogens causing stem blight and dieback of blueberry: L. theobromae and $N$. ribis. B. dothidea was not recovered from any samples in the two-survey farm. Species recovery was not dependent on location, season, or type of symptom (Table 1). Although L. theobromae was recovered from sample material less frequently than $N$. ribis, both species were recovered from stem blight and dieback samples. A preliminary study also confirmed that all three species were pathogenic on SHB in Florida (38). Recovery incidence and pathogenicity indicate that both species are economically important for the industry because they have the potential to reduce yield and field longevity. Therefore, management strategies need to be developed which control both pathogens.

Witcher and Clayton (36) described $B$. dothidea as the causal agent of blueberry stem blight. The morphology of $N$. ribis isolates recovered from SHB in Florida was consistent with Witcher and Clayton's original description of the pathogen. Isolates produced a yellow pigment on PDA, and mycelium growth rate and conidia dimensions for $N$. ribis isolates were similar to the original studies' description (Table 4). In 2004, $N$. ribis was separated from $B$. dothidea (21) and another closely related species, $N$. parvum. In 2009, the $N$. parvum-N. ribis complex was further split into several cryptic species using genea-

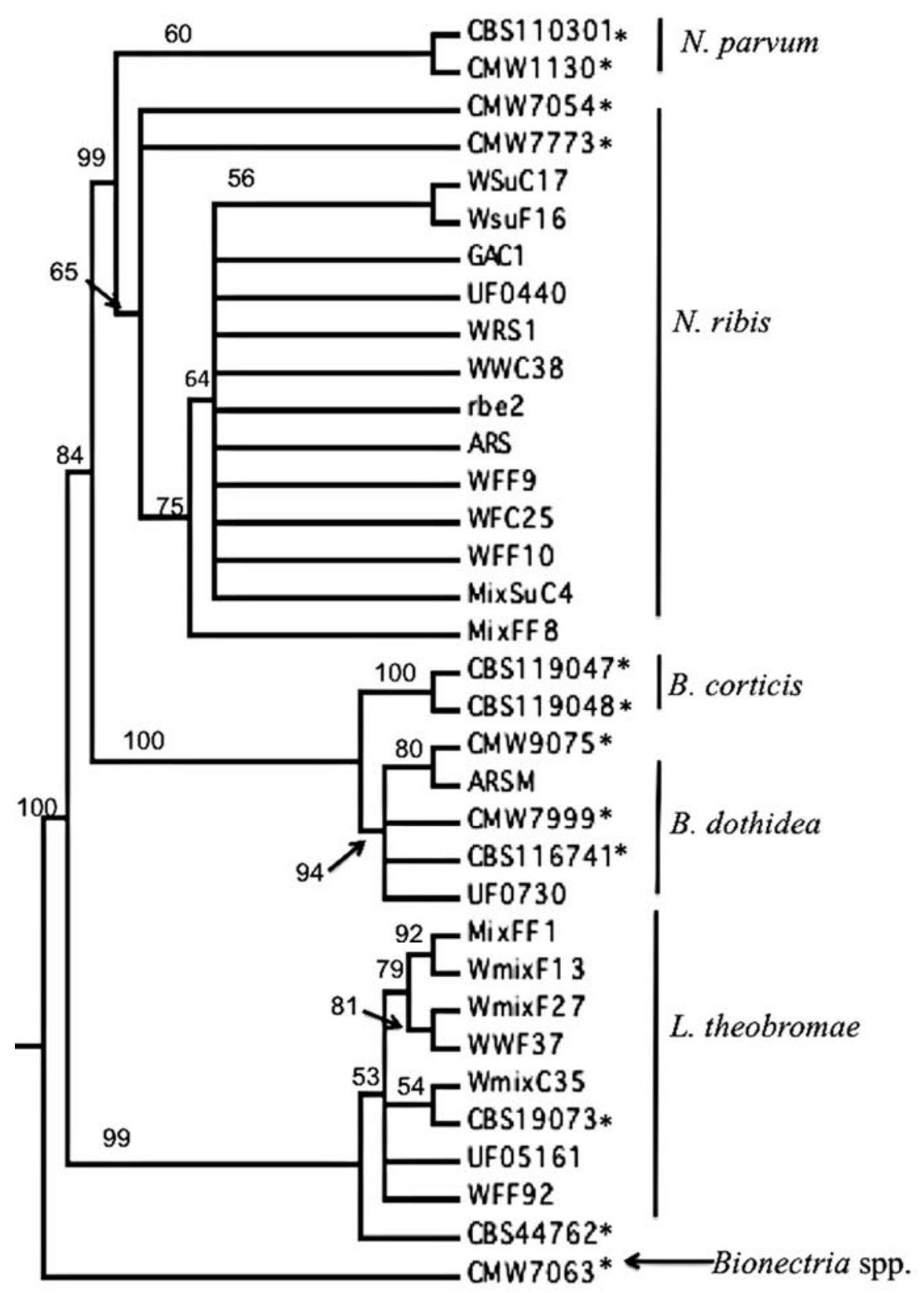

Fig. 1. Most equally parsimonious tree using 1,000 bootstrap and 100 random addition sequence replicates in PAUP. A partial sequence of the internal transcribed spacer (ITS1, 5.8S, and ITS2) and the elongation factor $1-\alpha(E F 1-\alpha)$ from species in the family Botryosphaeriaceae were used to generate the consensus tree. Asterisks indicate isolates from previous studies.

logical concordance of phylogenetic species recognition (GCPSR) (16). Our results confirm that one of the two causal agents of stem blight of SHB in Florida belongs within the $N$. ribis species complex.

The ITS region alone could not statistically separate $N$. ribis from $N$. parvum, and a partial sequence of the EF1- $\alpha$ region was needed to place our isolates $(9,21,31)$. Within the $N$. ribis clade, our isolates formed a separate group (Fig. 1). Phylogenetic variation could be due to regional adaptation and genotypic recombination. The addition of other phylogenetic informative regions, including a portion of the RNA polymerase II subunit, should be analyzed to confirm the exact grouping of the Floridian isolates within the $N$. ribis clade (16).

The second species identified as causing stem blight of SHB was $L$. theobromae. The association of $L$. theobromae as the casual agent of stem blight of SHB was recently reported (37). Conidial morphology for $L$. theobromae isolates was consistent with the species descriptions (Table 4). Immature conidia were hyaline with a thick cell wall and were single celled with granular contents. Conidia became single septate with age, and dark brown with black longitudinal striations $(2,9)$. Phylogenetic analysis confirmed morphological identification and grouped isolates within the L. theobromae clade (Fig. 1). Genetic variation was present in the $L$. theobromae clade, which could be due to regional adaptation.

The sexual state of $L$. theobromae was not observed on any of the sample material. However, the majority of samples found producing conidia were identified as $L$. theobromae and predominantly were observed during the fall of 2007. Observations were inconsistent with previous conidial production studies. Peak sporulation months for $B$. dothidea were June to July for blueberry in North Carolina (8) and August for peaches in Georgia (32). Variation are likely due to differences in climate, geographic location, and fungal species. Additional sporulation studies are needed to verify when conidia of $L$. theobromae and $N$. ribis are produced in Florida.

One B. dothidea isolate was obtained from a plant with a foliar ring spot symptom outside the survey. Additional samples with similar symptoms did not yield the fungus. Foliar inoculation studies with $B$. dothidea were not conducted, and additional work is needed to determine whether $B$. dothidea was causing these symptoms or existing as a foliar endophyte.

Surprisingly, B. dothidea was identified infrequently and was not recovered from any of the sample material in the survey. Low occurrence could be due to taxonomic reevaluation of the species (21). Recovery frequency of species in the family Botryosphaeriaceae has been reported to be 
different depending on geographic location (30). The survey also includes data from only 1 year; therefore, shifts in populations from year to year are a possibility. Continued periodic sampling of stem blight pathogens in Florida and the southeastern United States will help further define dynamics of the pathogen populations affecting the industry in the region. Sequence data collected to date will be used to develop PCR protocols to help distinguish between these species without the need to obtain sequences of multiple loci per isolate. Such protocols could help diagnosticians that routinely use PCR to differentiate these fungi; however, there are no practical management implications presented here that would support the added expense and effort. Although N. ribis and L. theobromae are the primary stem blight pathogens of SHB in Florida, additional work is needed before conclusions are drawn concerning other plant species and other blueberry-producing regions.

\section{ACKNOWLEDGMENTS}

We gratefully acknowledge funding from United States Department of Agriculture NIFA award no. 2008-51180-19579 (Specialty Crop Research Initiative). We thank the Florida Blueberry Growers' Association and its members for funding and supporting this research; Straughn Farms and Mixon Family Farms for their cooperation and assistance with survey work; and P. Hill and C. Yankee for their assistance in the lab.

\section{LITERATURE CITED}

1. Alfieri Jr., S. A., Landon, K. R., Kimbrough, J. W., El-Gholl, N. E., and Wehlburg, C. 1994. Diseases and disorders of plants in Florida. Dep. Plant Ind. Bull. No. 14:1-1115. Gainesville, FL.

2. Alves, A., Crous, P. W., Correia, A., and Phillips, A. J. L. 2008. Morphological and molecular data reveal cryptic species in Lasiodiplodia theobromae. Fungal Div. 28:1-13.

3. Britton, K. O., and Hendrix, F. F. 1986. Population dynamics of Botryosphaeria spp. in peach gummosis cankers. Plant Dis. 70:134136.

4. Britton, K. O., Hendrix, F. F., Pusey, P. L., Okie, W. R., Reilly, C. C., and Daniel, J. W. 1990. Evaluating the reaction of peach cultivar to infection by three Botryosphaeria species. HortScience 25:467-470.

5. Brown, E. A., and Hendrix, F. F. 1981. Pathogenicity and histopathology of Botryosphaeria dothidea on apple stems. Phytopathology 71:375-378.

6. Burgess, T. I., Taylor, A., Hardy, G., and Wood, P. 2005. Identification and pathogenicity of Botryosphaeria species associated with grapevine decline in Western Australia. Australas. Plant Pathol. 34:187-195.

7. Carbone, I., and Kohn, L. M. 1999. A method of designing primer sets for speciation studies in filamentous ascomycetes. Mycologia 91:553556.

8. Creswell, T. C., and Milholland, R. D. 1988. Spore release and infection periods of Botryosphaeria dothidea on blueberry in North
Carolina. Plant Dis. 72:342-346.

9. Crous, P. W., Slippers, B., Wingfield, M. J., Rheeder, J., Marasas, W. F.., Phillips, A. J. L., Alves, A., Burgess, T., Barber, P., and Groenwald, J. Z. 2006. Phylogenetic lineages in the Botryosphaeriaceae. Stud. Mycol. 55:235-253.

10. Denman, S., Crous, P. W., Taylor, J., Kang, J., Pasco, I., and Wingfield, M. 2000. An overview of the taxonomic history of Botryosphaeria and a re-evaluation of its anamorphs based on morphology and ITS rDNA phylogeny. Stud. Mycol. : 129-140.

11. Jacobs, K. A., and Rehner, S. A. 1998. Comparison of cultural and morphological characters and ITS sequences in anamorphs of Botryosphaeria and related taxa. Mycologia 90:601-610.

12. Ma, Z., and Michailides, T. J. 2002. Characterization of Botryosphaeria dothidea isolates collected from pistachio and other plant hosts in California. Phytopathology 92:519-526.

13. Maddison, D. R., and Maddison, W. R. 2000. McClade 4: Analysis of Phylogeny and Character Evolution. Sinauer Associates. Sunderland, MA.

14. Michailides, T. 1991. Pathogenicity, distribution, sources of inoculum, and infection courts of Botryosphaeria dothidea on pistachio. Phytopathology 81:566-573.

15. Milholland, R. D. 1972. Histopathology and pathogenicity of Botryosphaeria dothidea on blueberry stems. Phytopathology 62:654-660.

16. Pavlic, D., Slippers, B., Coutinho, T., and Wingfield, M. J. 2009. Multiple gene genealogies and phenotypic data reveal cryptic species of the Botryosphaeriaceae: a case study on the Neofusicoccum parvum/N. ribis complex. Mol. Phylogenet. Evol. 51:259-268.

17. Pennycook, S. R., and Samuels, G. J. 1985. Botryosphaeria and Fusicoccum species associated with ripe fruit rot of Actinida deliciosa (Kiwifruit) in New Zealand. Mycotaxon 24:445-458.

18. Phillips, A. J. L., Oudemans, P. V., Correia, A., and Alves, A. 2006. Characterization and epitypification of Botryosphaeria corticis the cause of blueberry cane canker. Fungal Div. 21:141-155.

19. Rayachhetry, M. B., Blakeslee, G. M., and Miller, T. 1996. Histopathology of Botryosphaeria ribis in Melaleuca quinquenervia: pathogen invasion and host response. Int. J. Plant Sci. 157:219-227.

20. Sanchez, M. E., Venegas, J., Romero, M. A., Phillips, A. J. L., and Trapero, A. 2003. Botryosphaeria and related taxa causing oak canker in southwestern Spain. Plant Dis. 87:15151521.

21. Slippers, B., Crous, P. W., Denman, S., Countinho, T. A., Wingfield, B. D., and Wingfield, M. J. 2004. Combined multiple gene genealogies and phenotypic characters differentiate several species previously identified as Botryosphaeria dothidea. Mycologia 96:83-101.

22. Slippers, B., Johnson, G. I., and Cous, P. W. 2005. Phylogenetic and morphological reevaluation of the Botryosphaeria species causing diseases of Mangifera indica. Mycologia 97:99-110.

23. Slippers, B., Smit, W. A., Crous, P. W., Countinho, T. A., Wingfield, B. D., and Wingfield, M. J. 2007. Taxonomy, phylogeny and identification of Botryosphaeriaceae associated with pome and stone fruit trees in South Africa and other regions of the world. Plant Pathol. 56:128-139.
24. Smith, C. O. 1934. Inoculations showing the wide host range of Botryosphaeria ribis. J. Agric. Res. 49:467-476.

25. Smith, D. R., and Stanosz, G. R. 2000. Molecular and morphological differentiation of Botryosphaeria dothidea (anamorph Fusicoccum aesculi) from some other fungi with Fusicoccum anamorphs. Mycologia 93:505515.

26. Swaford, D. L. 2002. PAUP*. Phylogenetic Analysis Using Parsimony (*and other methods), 4.0 Beta. Sinauer Associates, Sunderland, MA.

27. Swart, L., Crous, P. W., Petrini, O., and Taylor, J. E. 2000. Fungal endophytes of Proteaceae, with particular emphasis on Botryosphaeria proteae. Mycoscience 41:123-127.

28. Thompson, J., Gibson, T., Plewniak, F., Jeanmougin, F., and Higgins, D. 1997. The Clustal $\mathrm{X}$ Windows Interface: flexible strategies for multiple sequence alignment aided by quality analysis tools. Nucleic Acids Res. 25:48764882.

29. Úrbez-Torres, J. R., Leavitt, G., Guerrero, J. C., Guevara, J., and Gubler, W. D. 2008. Identification and pathogenicity of Lasiodiplodic theobromae and Diplodia seriata, the causal agent of Bot canker disease of grapevines in Mexico. Plant Dis. 92:519-529.

30. Úrbez-Torres, J. R., Leavitt, G. M., Voegel, T. M., and Gubler, W. D. 2006. Identification and distribution of Botryosphaeria spp. associated with grapevine cankers in California. Plant Dis. 90:1490-1503.

31. van Niekerk, J. M., Crous, P. W., Groenewald J. Z., Fourie P. H., and Halleen, F. 2004. DNA phylogeny, morphology, and pathogenicity of Botryosphaeria species on grapevines. $\mathrm{My}$ cologia 96:781-798.

32. Weaver, D. J. 1978. Role of conidia of Botryosphaeria dothidea in the natural spread of peach tree gummosis. Phytopathology 69:330334.

33. White, J., Bruns, T., Lee, S., and Taylor, J. 1990. Amplification and direct sequencing of fungal ribosomal RNA genes for phylogenetics, Pages 315-322 in: PCR Protocols, A Guide to Methods and Applications. M. A. Innis, D. J. Gelfand, and J. J. Sninshky, eds. Academic Press Inc., New York.

34. Williamson, J. G., and Lyrene, P. M. 2004. The Florida blueberry industry: a decade of growth. Proc. Fla. State Hortic. Soc. 117:234-235.

35. Willamson, J. G., Lyrene, P. M., Weitt, T. D., and Ruppert, K. C. 2004. Alternative Opportunities for Small Farms: Blueberry Production Review. RF-AC008. UF/IFAS Extension EDIS.PUB., Gainesville, FL.

36. Witcher, W., and Clayton, C. N. 1962. Blueberry stem blight caused by Botryosphaeria dothidea (B. ribis). Phytopathology 53:705712.

37. Wright, A. F., and Harmon, P. F. 2009. First report of Lasiodiplodia theobromae causing stem blight of southern high bush blueberries in Florida. Plant Dis. 93:692.

38. Wright, A. F., and Harmon, P. F. 2009. Morphological identification and pathogenicity of Botryosphaeria spp. causing stem blight on southern highbush blueberries in Florida. (Abstr.) Phytopathology 99:S143.

39. Zhou, S., and Stanosz, G. R. 2001. Relationships among Botryosphaeria species and associated anamorphic fungi inferred from the analysis of ITS and 5.8S rDNA sequences. Mycologia 93:515-526. 